\title{
Vocational Education in Negro High Schools in Texas
}

\author{
IRA B. BRyant \\ Principal, Booker T. Washington High School, Houston, Texas
}

\section{INTRODUCTION}

The Negro today finds himself engaged in many regressive occupational fields, and of the many contributing factors to this condition probably two of the more significant ones are racial antipathy and lack of preparation. If Negroes are to maintain their present occupational status or extend it in skilled and unskilled fields, they must receive adequate training either through the schools or through other institutions established for that purpose. The most practical method by which workers are trained for the crafts is through apprenticeship under supervision of labor unions - a practice denied Negroes in the South, for the most part. Since this situation exists, it becomes the added responsibility of the schools to give this training. School administrators cannot continue to neglect the urgent demands for a more practical vocational educational program for Negroes.

New occupational opportunities were created for Negroes during World War II when there was increased demand for manpower for the production of necessary material. A special training program was imperative to meet this demand for skilled workers. These facts seem to indicate that the educational program is faulty, and should be revised. However, few factual data have been gathered to support or refute this controversial issue.
It is obvious that there are many problems which must be solved before education at the secondary level can be made more effective occupationally for Negroes in the South. Many problems fall within range of that phase of the curriculum known as vocational education. Any study concerned with vocational programs will be a step toward making that part of the curriculum more effective. This study does not purport to solve all of the problems, but rather to reveal some of the major facts in the field of vocational education.

\section{Purposes of the Study}

The purposes of this study were: (1) to survey a representative number of high schools for Negroes in Texas in order to ascertain what vocational courses are offered in the curriculums; (2) to analyze and evaluate the offerings in the light of social and economic conditions faced by Negroes; and (3) on the basis of significant findings, to offer constructive suggestions toward a new vocational educational program.

The major problems of this investigation are: First, what are the vocational offerings of the Negro high schools of Texas? Second, for what occupational fields are Negro pupils trained under the present vocational education program of Texas? Third, to what extent do these vocational education programs lead to traditional Negro jobs? Fourth, to what ex- 
tent do these vocational offerings lead to skilled and semi-skilled occupations? Fifth, to what extent are Negro workers trained for the jobs they hold? Sixth, on the basis of present and future trends, what method of vocational training is the most feasible in the secondary schools for Negroes in Texas?

\section{Procendue}

The data for the investigation were secured through the use of two types of questionnaires-vocational questionnaires sent to the principals of 73 urban and 72 rural high schools for Negroes, and occupational questionnaires distributed to 6,000 Negro workers in fifteen selected occupational areas. These high schools were selected on the basis of city population and the rating of the schools by the Texas State Department of Education. The selection of the occupational areas was based on (1) the number of Negroes employed, (2) accessibility of the workers, (3) the possibility of schools offering training in certain fields, (4) whether occupation is regressive or not, (5) fields which Negro high school graduates, for the most part, are forced to enter, and (6) financial returns.

Of the principals to whom questionnaires were sent, 64.7 per cent responded, and of the questionnaires distributed to workers in the occupational areas, 55.1 per cent were used for this investigation.

\section{Results}

College Preparatory and Vocational Offerings of the High Schools for Negroes.-A study of the data revealed that 15,340 pupils were en- rolled in the urban and rural schools investigated, or 54.8 per cent of the total enrollment $(27,991)$ of secondary schools for Negroes in Texas (1945-1946).

A more important fact revealed by the data is that out of 2,221 pupils graduating from all schools of this investigation, only 977 or 43.9 per cent enrolled in college. As to graduates who did not go to college, the questionnairs from 33 of the 35 urban schools responding and from 49 of the 59 rural schools indicated that such graduates, for the most part, had entered the field of domestic and personal service.

The evidence disclosed that the range of vocational offerings of the secondary schools is small and narrow, consisting very largely of vocational agriculture, trades sewing, trades cooking, typing and shorthand, bookkeeping, and auto-mechanics. It was also brought to light that with the exception of welding, which is offered in one rural school, and radio engineering, which is offered in two urban schools, there seems to be complete agreement between the two classes of schools as to the type of vocational courses offered. Further, the facts revealed that the secondary schools for Negroes train, for the most part, for the professions, and that the pupils in these schools are not taking advantage of the small range of vocational courses offered. There was evidence also that the scope of training for skilled occupational areas in the above mentioned schools covers auto mechanics, sheet metal work, and radio engineering only.

Availability of Vocational Education to Negroes in Texas.-According 
to the facts obtained, the curriculums of secondary schools for Negroes in Texas are very largely college preparatory. That 96.7 per cent of the students in the urban high schools included in this study were taking courses leading to college entrance, confirms this fact. The curriculums of the rural high schools for Negroes in Texas, as they relate to college offerings, do not differ significantly from those of the urban high schools.

The types of vocational courses offered in the urban and rural high schools are much the same with the possible exception of emphasis only. The vocational courses of these schools according to the reports, consist of a small homogeneous range of courses. This fact suggests that little consideration has been given to the variability of occupational differences that occur in different sections of the State. The facts also indicate that the larger percentage of Negro pupils are enrolled in vocational courses that lead to occupational areas which are not unionized and therefore do not offer competition to white workers. The data further showed that the Federally-Aided Vocational Program for Negroes, for the most part, has been confined to two services only: agriculture and home economics.

In a comparison of the vocational offerings of the secondary schools for Negroes in Texas and those of the Texas Prison System for Negroes, it was revealed that there were five occupational areas: machinists, plumbing, Diesel engine operation, refrigeration and air conditioning, in which Negro prisoners may receive training that cannot be obtained by Negro pupils in the secondary schools of the State.

Occupational Training of Negro Workers in Texas.-The data on the occupational status of skilled and unskilled Negro workers in Texas were secured from 3,308 questionnairesthe number used out of 6,000 which had been distributed among these workers through labor unions, high schools for Negroes in Houston and Dallas, and four selected rural communities.

The areas of skilled occupations in which data were sought were those of auto-mechanics, carpenters, longshoremen, machinist helpers, movie projectionists, plumbers, printers, and railroad workers (blacksmiths and mechanies).

Data obtained on the unskilled workers included beauticians and barbers, chauffeurs and truck drivers, laundry workers, cooks and waiters, maids and porters, household workers, and farmers.

An analysis of the data secured on the skilled workers showed that the educational background of this elass ranged from the first grade through college; that out of 1,127 workers only 65 had attended any trade school; and that only one had received training for the trade at the high school level. The grade medium was found to be 7.8 .

As to the workers in the unskilled class, which numbered 2,181, the facts disclosed that their educational background ranged from 18 who had never attended school to 23 who had finished college, and that only 59 had received special training in a trade school. The grade median for these workers was found to be 8.0 . 
Occupational Status of Negroes in Texas.-A factor that seems to influence the type of occupations in which the Negro is engaged in Texas is the trade union. There are three such unions active in the State of Texas: the American Federation of Labor, the Congress on Industrial Organization, and the Independent or Company Unions. The influence of these organizations varies. In some instances it is direct; in others, it is indirect and subtle. It is safe to state that regardless of whatever methods the unions have used to make their influence felt, Negro workers have been relegated to definite low-paying, unskilled occupational areas.

According to the data, the most common occupational areas for $\mathrm{Ne}$ groes in Texas are those of chauffeurs $(9,431)$, domestic workers $(94,751)$, and service workers $(41,267)$, or a total of 145,449 workers. These figures reveal that 42.9 per cent of all Negro workers in Texas are concentrated in these areas. However, the increasing need for manpower during the war (World War II) enhanced the occupational status of Negroes in Texas. Recent reports on the total employment in selected war industries in Texas show that Negroes comprise an increasingly large percentage of the total number of workers in the following areas: iron and steel, machinery, chemicals, ordnance, petroleum refining, shipbuilding, synthetic rubber, non-ferrous metals, and aircraft.

Occupational Trends and Opportunities.-One of the paramount questions which arise in the process of formulating a program of vocational education is : what is the occupational outlook? This question can be answered only by obtaining a clear picture of these three phases of occupational trends: general occupational trends, occupational trends affecting Negro workers, and the change of policy of labor unions toward Negro workers.

The general trends indicate very clearly that employment prospects will be best for those who are trained for a specific occupational area. In addition to the general occupational trends affecting all racial groups are those which are of special significance to Negro workers. The changing occupational status of the white man is seriously affecting the occupational status of the Negro worker. Technical improvements have brought many jobs that were traditionally "Negro jobs" to the attention of white workers. This fact seems constantly to force Negroes in increasingly large numbers into menial, low-paying occupational areas and unemployment. Current documentary evidence indicates that Negroes have been losing ground in many of their historic occupations in the South. On the other hand, current literature shows that thousands of new job opportunities have opened up for trained Negro workers.

One of the major occupational trends affecting Negro workers is the change of racial policies by labor unions, particularly the American Federation of Labor. This organization boasts 750,000 Negro workers in the United States, of which 450,000 are in the South. The Congress of Industrial Organization has exemplified, from its inception, a policy of racial equality. 
On the basis of the facts presented, it appears that employment opportunities for Negroes are almost unlimited in any area which they may be trained. However, only seven occupational areas in which Negroes in Texas might be trained consistent with employment demands and opportunities were pointed out and matched with the following evaluative criteria: (1) the number of workers in the occupation; (2) the extent to which training in the occupation is practical; (3) the availability of training under the present educational facilities; (4) the degree to which Negroes will be accepted on the job by whites, or be able to make employment opportunities for themselves; (5) occupational fields in which $\mathrm{Ne}-$ groes are traditionally employed; (6) whether the occupation is regressive or not; and (7) adequate financial returns.

When the above criteria were applied to the occupational areas-(1) building trades and related fields ; (2) industrial trades and related fields; (3) printing and related fields; (4) commercial trades and related fields; and (6) agriculture and related fields -it was found that each field except that of domestic and personal service matched favorably. On the basis of the evidence presented, it was suggested that vocational training be made available to Negro pupils in each of the aforementioned occupational areas. It was also suggested that school officials reconsider the present industrial arts curriculum with the view of developing fewer and more efficient workers, whose services will demand higher wages and better working conditions.
A Minimum Vocational Educational Program for Negroes in Texas. The proposed minimum vocational educational program for Negroes in Texas offers two methods of training: onthe-job and in-school.

The on-the-job method of vocational training is suggested for the following reasons: (1) it is very unlikely that school authorities will furnish schools for Negroes with adequate equipment to train them for effective participation in community employment; (2) there are many small $\mathrm{Ne}-$ gro business men who are willing to cooperate with an on-the-job training program and to provide both the instruction and the equipment in exchange for labor at a reasonable wage.

It is suggested that the following steps be taken in establishing the onthe-job training program: (1) that a survey be made of the vocational opportunities of the school area; (2) that a trade committee be appointed to assist in the selection both of the industrial agency and of equipment, and also of the organization of teaching content; (3) that an effort be made to secure State and Federal Aid through proper qualification; and (4) that pupils be selected on the basis of specific essentials.

Such a program would have the following advantages: small schools could provide economical vocational training; potential workers would receive on-the-job experience; the pupil would receive job adjustment before graduation; courses would rot be added or eliminated from the curriculum without the endorsement of the community; and the school and industry would be in complete agree- 
ment on the objectives of all vocational courses.

The in-school method of training is designed for the large cities or areas that are able financially to give this type of vocational training; and these are the suggested lines along which such training should be established: (1) high schools should set up both industrial arts and vocational education courses, the former being a prerequisite to the latter; (2) schools should permit pupils to devote onehalf of the school day to practical shop work, and the other to related technical and non-technical instruction; (3) this in-school method should provide broad, basic training in the major industrial fields of the immediate school area.

The following advantages would result from a program which offers such training: (1) It would be especially adapted for vocational programs in large cities; (2) it would enable pupils to have a wide range of vocational offerings from which to choose; (3) it would permit schools to offer specialized training in a few occupational areas; (4) it would keep the schools in touch with rapidly changing industrial techniques in performing new tasks.

\section{Conclusions}

On the basis of this report, the following conclusions are reached:

1. Too great emphasis is placed on the college preparatory curriculum by both urban and rural high schools in Texas.

2. If, in the future, Negro workers are not given on-the-job or in-school vocational training, many occupational gains made during World War II will be lost.

3. The present curriculums of the Negro high schools of Texas are such that they are forcing graduates into the already over-crowded domestic service field, an occupation in which wages are low and the hours long.

4. The curriculum of the high schools for Negroes in Texas is geared for the preparation of that small percentage of pupils who will continue their education beyond the secondary level.

5. While it is true that owing to the shortage of manpower during World War II there was a rapid increase in the employment of Negro workers in many skilled and semiskilled occupations in Texas, in the future, such workers must be trained.

6. The changing policy of Labor Unions in regard to Negro memberships has opened new job opportunities for Negroes; and the responsibility of developing the efficiency of the Negro worker for such opportunities will rest very largely with the schools.

7. The integration of Negro workers in the future will probably be based more on efficiency than on race.

8. There is need for community action to convince the taxpayer that through vocational training not only is the Negro's standard of living raised but also that of the entire community.

9. The achievement of a better vocational educational program for $\mathrm{Ne}$ groes in Texas will come through inter-racial understanding and cooperation. 


\section{RECOMMENDATIONS}

In the view of the findings and conclusions, the following recommendations are offered:

1. That the Negro high schools of Texas place greater emphasis on vocational education and vocational guidance.

2. That the opportunities for commercial and trade education be increased to take care of the needs, interests, and abilities of those pupils who will not go to college.

3. That pupils in the Negro high schools of Texas be given the opportunity to study the requirements of all jobs in their particular communities.
4. That Negro schools in Texas put greater emphasis on training for replacement in the skilled occupations.

5. That the Federal Government insist on proper controls in the disbursement of Federal funds by States, in order that these funds may be distributed in proportion to the two racial groups served.

6. That the schools undertake to teach the parents of Negro children through parent-teacher associations, forums, and community projects that there is dignity not only in professional labor but in all labor.

7. That pupils should be encouraged to enter vocations in accordance with their abilities, interests, and aptitudes. 